\title{
Solid state fluorescence of proteins in high throughput mode
}

\section{and its applications [version 1; peer review: 2 approved with}

\section{reservations]}

\author{
Saurabh Gautam (D), Munishwar N Gupta \\ Department of Chemistry, Indian Institute of Technology Delhi, New Delhi, 110016, India
}

V1 First published: 11 Mar 2013, 2:82
https://doi.org/10.12688/f1000research.2-82.v1
Latest published: 25 Mar 2019, 2:82

https://doi.org/10.12688/f1000research.2-82.v2

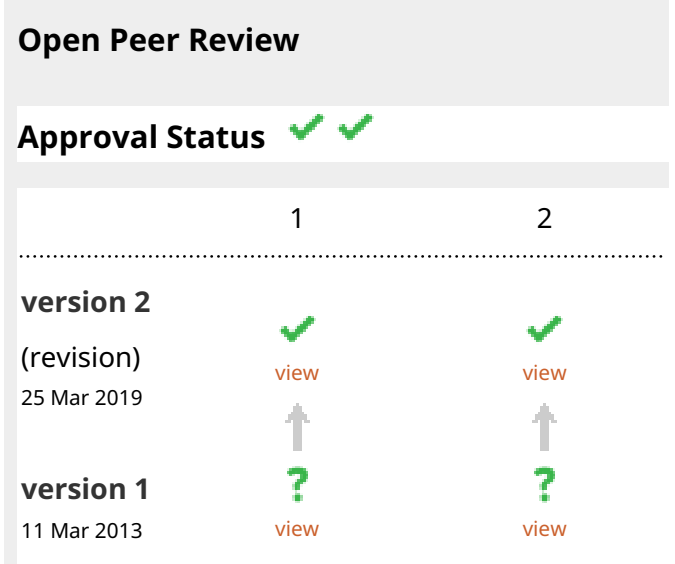

1. Vincent Rotello, University of Massachusetts Amherst, Amherst, MA, USA

2. Vladimir Uversky , University of South

Florida, Tampa, FL, USA

Any reports and responses or comments on the article can be found at the end of the article. 
powder was decreased significantly to $17 \%$ as compared to GFP in solution, and showed a red shift of $4 \mathrm{~nm}$ in the emission $\lambda_{\max }$. It was found that fluorescence resonance energy transfer (FRET) between tryptophan (Trp57) and the cyclic chromophore of GFP was significantly diminished. This indicated the change in the microenvironment around the cyclic chromophore in GFP upon lyophilization.

Corresponding author: Munishwar N Gupta (appliedbiocat@yahoo.co.in)

Competing interests: No competing interests were disclosed.

Grant information: This work was funded by research support from the Department of Biotechnology (DBT) [Grant number: BT/PR14103/BRB/10/808/2010] and the Department of Science and Technology (DST) [Grant number: SERB/F/1776/2011-2012], Government of India. Financial support was also provided by the Council of Scientific and Industrial Research to SG in the form of a Junior Research Fellowship.

The funders had no role in study design, data collection and analysis, decision to publish, or preparation of the manuscript.

Copyright: $\odot 2013$ Gautam S and Gupta MN. This is an open access article distributed under the terms of the Creative Commons Attribution License, which permits unrestricted use, distribution, and reproduction in any medium, provided the original work is properly cited. Data associated with the article are available under the terms of the Creative Commons Zero "No rights reserved" data waiver (CC0 1.0 Public domain dedication)

How to cite this article: Gautam S and Gupta MN. Solid state fluorescence of proteins in high throughput mode and its applications [version 1; peer review: 2 approved with reservations] F1000Research 2013, 2:82

https://doi.org/10.12688/f1000research.2-82.v1

First published: 11 Mar 2013, 2:82 https://doi.org/10.12688/f1000research.2-82.v1 


\section{Introduction}

Fluorescence spectroscopy is a powerful tool to study protein structure $^{1-3}$. Measurement of the fluorescence of proteins, when the latter is present in the solid state, is useful in several different contexts. Solid state fluorescence has a number of uses including in protein assays with protein electrophoresis samples $^{4}$, enzyme immobilization ${ }^{5}$, microscopy ${ }^{6}$, detecting changes in protein tertiary structure upon lyophilization ${ }^{7}$, sensors and microarrays $^{8,9}$ and characterizing solid waste ${ }^{10}$. Of these, fluorescence measurement of lyophilized samples is itself valuable for a variety of different kinds of studies. Enzyme catalysis in low water media is often carried out with lyophilized enzyme powders ${ }^{11-14}$. Only recently, circular dichroism (CD) of $\alpha$-chymotrypsin "dried” (bulk water removed) with different methods has been reported with the help of a special accessory for recording CD spectra of solid samples as suspensions ${ }^{15}$.

Some commercially available accessories for spectrofluorimeters allow recording the fluorescence emission spectra of the solid samples ${ }^{7,16-19}$. These available commercial accessories can only accommodate solid samples and hence do not allow a direct comparison between fluorescence spectra of a sample in solution and solid state form. These accessories also do not allow working in a high throughput mode.

We describe here a simple method for recording fluorescence emission spectra of protein powders without using any dedicated accessory. This method works with a 96-well plate format. It enables the comparison of fluorescence spectra of a sample in a solid state with solution spectra, using comparable quantities of protein. It was found that, just like spectra recorded with these commercial accessories, the spectra of lyophilized powders obtained by our method showed a blue shift of $\lambda_{\text {max }}$ (as compared to the solution spectra). After this validation, the method was used for two specific applications. In the first case, the method was used for assessing the tertiary structure of "dried" $\alpha$-chymotrypsin. It was also used to track changes in fluorescence spectra of green fluorescent protein (GFP) when it is dried. While the former application is relevant to non-aqueous enzymology, the latter provides some insight into fluorescence resonance energy transfer (FRET) between tryptophan of GFP (Trp57) and its cyclic chromophore ${ }^{20,21}$.

These illustrative examples show that the valuable information provided by fluorescence emission spectroscopy about conformational changes in proteins upon drying can be obtained in a simple manner by anybody with a fluorescence-based microplate reader.

\section{Materials}

Ampicillin, bovine serum albumin (BSA, cat. no. A7030), $\alpha$-chymotrypsin (protease from bovine pancreas, cat. no. C4129), lysozyme (from chicken egg white, cat. No. L6876), phenylmethanesulfonylfluoride (PMSF) and n-propanol were purchased from Sigma-Aldrich (St. Louis, MO, USA). Isopropyl $\beta$-D-thiogalactopyranoside (IPTG) and LB medium were obtained from Himedia Laboratories (Mumbai, India). TLL (Thermomyces lanuginosus lipase) was a kind gift from Novozymes (Denmark). Candida rugosa lipase was a gift from Amano Enzyme Inc. (Nagoya, Japan). Ninety-six well polystyrene microplates were obtained from Porvair Sciences (Leatherhead, UK). All other chemicals used were of analytical grade. All the proteins used were $>95 \%$ pure on SDS-PAGE.

\section{Overexpression and isolation of GFP}

The plasmid pGFPuv expressing recombinant GFP was transformed into $E$. coli BL21(DE3) ${ }^{22}$. A single colony was picked and inoculated into $5 \mathrm{~mL} \mathrm{LB}$ medium containing $100 \mu \mathrm{g}$ $\mathrm{mL}^{-1}$ ampicillin. In total, $1 \%$ of primary inoculum was transferred into $1 \mathrm{~L}$ fresh $\mathrm{LB}$ broth $\left(\mathrm{amp}^{+}\right)$and grown at $37^{\circ} \mathrm{C}$ with shaking at $200 \mathrm{rpm}$ until absorbance at $600 \mathrm{~nm}$ reached 0.8 . Induction was carried out by adding $1 \mathrm{mM}$ isopropyl $\beta$-Dthiogalactopyranoside (IPTG) (final concentration). The culture was further grown under similar conditions for $12 \mathrm{~h}$. The cells were harvested by centrifugation at $8000 \mathrm{~g}$ for $10 \mathrm{~min}$ at $4^{\circ} \mathrm{C}$. GFP was isolated from E. coli cells by sonication in 50 $\mathrm{mM}$ phosphate buffer, $\mathrm{pH} 7.5$, containing $2 \mathrm{M} \mathrm{NaCl}$ and 100 $\mu \mathrm{M}$ phenylmethanesulfonylfluoride (PMSF), three times with $15 \mathrm{~s}$ pulses on ice, and centrifugation at $9000 \mathrm{~g}$ for $10 \mathrm{~min}$ at $4^{\circ} \mathrm{C}$. The supernatant thus obtained was used as a crude extract for GFP and further purified to homogeneity (as shown by single band on SDS-PAGE) by immobilized metal affinity chromatography using nickel-alginate beads as described earlier ${ }^{22}$.

\section{Lyophilization}

Lyophilization of all the proteins was carried out on a freeze dryer from Allied Frost (New Delhi, India). Proteins were dialyzed against buffer (10 mM Tris- $\mathrm{HCl}, \mathrm{pH} 7.0$ for BSA, TLL, lysozyme, CRL and $\alpha$-chymotrypsin; and $10 \mathrm{mM}$ phosphate buffer, $\mathrm{pH} 7.5$ for GFP) and were frozen at $-70^{\circ} \mathrm{C}$ for $1 \mathrm{~h}$ before lyophilization.

\section{Preparation of enzyme precipitated and rinsed with propanol (EPRP) of $\alpha$-chymotrypsin}

Enzyme precipitated and rinsed with propanol (EPRP) of $\alpha$-chymotrypsin was prepared as described previously ${ }^{15}$. A total of $4 \mathrm{mg}$ of $\alpha$-chymotrypsin was dissolved in $400 \mu \mathrm{L}$ of $10 \mathrm{mM}$ Tris- $\mathrm{HCl}$ buffer, $\mathrm{pH}$ 7.8. Enzyme solution was then added drop wise to $4 \mathrm{ml}$ of n-propanol with stirring at $4^{\circ} \mathrm{C}$. After addition, the suspension was stirred for $30 \mathrm{~min}$ at $4^{\circ} \mathrm{C}$. The suspension was then centrifuged at $5000 \mathrm{~g}$ for $10 \mathrm{~min}$ at $4^{\circ} \mathrm{C}$, and the precipitate was rinsed three times with dry and chilled n-propanol.

\section{Fluorescence measurements}

All fluorescence spectra were recorded on a Cary Eclipse, Varian spectrofluorimeter (Varian Inc., Mulgrave, Victoria, Australia) at $25^{\circ} \mathrm{C}$ by using the microtitre plate reader accessory for 
reading 96-well microplates. The typical protein concentration of proteins used for fluorescence measurements in solution was $2 \mathrm{mg} / \mathrm{mL}$ in a total volume of $200 \mu \mathrm{L}$. Proteins were lyophilized at the same concentration and same amount of protein was used for solid state fluorescence measurements. The fluorescence emission spectra were recorded from $300 \mathrm{~nm}$ to $400 \mathrm{~nm}$ upon excitation at $280 \mathrm{~nm}^{2}$. For GFP, the fluorescence emission spectra were recorded from $450 \mathrm{~nm}$ to $600 \mathrm{~nm}$ upon excitation at $395 \mathrm{~nm}^{23}$. The excitation and emission slit widths were kept at $2 \mathrm{~nm}$ and $5 \mathrm{~nm}$, respectively. All fluorescence spectra were normalized and corrected for background contributions including the buffer.

\section{Estimation of protein concentration}

Protein concentration was estimated by the dye binding method using bovine serum albumin as the standard protein $^{24}$.

\section{Results and discussion}

The method developed here consists of simply placing the lyophilized powder of the protein in the well of 96-well microplate. The fluorescence spectra were recorded on a standard Varian microplate reader. The $\lambda_{\max }$ excitation known for the protein solutions were used for solid samples as well. Intrinsic fluorescence emission spectra of four different commercial proteins were obtained after lyophilization from the aqueous buffer and compared with the spectra of the respective protein in the aqueous buffer solution (Figure 1). The amount of protein in each solution was the same as was used for obtaining the lyophilized powders. In all the cases there was a blue shift in emission $\lambda_{\max }$ (Table 1) and an increase in the intensity of the emission spectra of the lyophilized proteins as compared to the protein in aqueous solution. It is important to note that a similar blue shift in the $\lambda_{\text {max }}$ have been reported by Ramachander et al. ${ }^{7}$ while comparing the solid state and solution state fluorescence spectra of four therapeutic proteins (the identities of the proteins were not disclosed by these authors). These workers had used a special accessory (called a solid state holder set up) for the Cary Eclipse spectrofluorimeter. The blue shift in the lyophilized state reflects that the environment of intrinsic fluorophores is more non-polar. This is expected due to the removal of water. The small differences in the extent of the blue shift (Table 1) in case of the four proteins presumably originate from the differences in the microenvironments of tryptophan in the folded structure of each of the proteins. To start with, when in solution, the microenvironments of tryptophan are expected to be different between different proteins.

Figure 2 shows the fluorescence emission spectra of $\alpha$-chymotrypsin in solution and in the solid state. Native $\alpha$-chymotrypsin in aqueous buffer showed emission $\lambda_{\text {max }}$ of $335 \mathrm{~nm}$ while upon lyophilization it was blue shifted to $328 \mathrm{~nm}$ with an increase in the intensity. This is likely again due to the non-polar
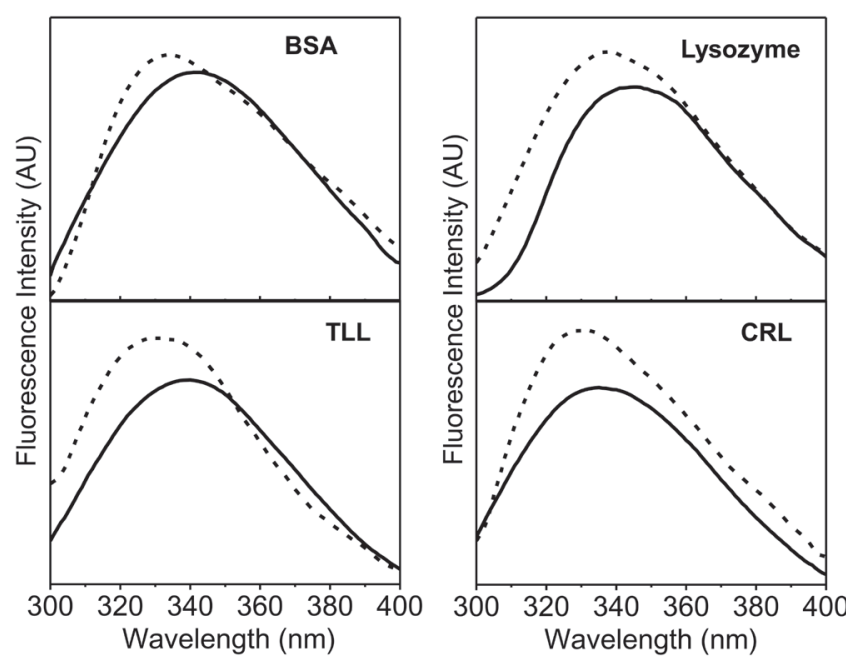

Figure 1 Fluorescence emission spectra (AU, arbitrary units) of four different proteins [Bovine serum albumin (BSA), Thermomyces lanuginosus lipase (TLL), Candida rugosa lipase (CRL)]. Protein in aqueous buffer (10 mM Tris-HCl, pH 7.0) (-) and lyophilized protein powder (- -). All these fluorescence emission spectra were recorded with excitation at $280 \mathrm{~nm}$ using excitation and emission slit widths of $2 \mathrm{~nm}$ and $5 \mathrm{~nm}$, respectively.

Figure 1 Fluorescence emission spectra of bovine serum albumin (BSA), Thermomyces lanuginosus lipase (TLL), Candida rugosa lipase (CRL).

4 Data Files

http://dx.doi.org/10.6084/m9.figshare.640095

Table 1 Fluorescence emission $\lambda_{\text {max }}(\mathrm{nm})$ of four different lyophilized proteins and their comparison with the proteins in $10 \mathrm{mM}$ Tris- $\mathrm{HCl}$, pH 7.0.

\begin{tabular}{|llll}
\hline Protein & $\begin{array}{l}\lambda_{\max }(\mathrm{nm}) \text { of the } \\
\text { protein in aqueous } \\
\text { buffer solution }\end{array}$ & $\begin{array}{l}\lambda_{\max }(\mathrm{nm}) \text { of } \\
\text { the lyophilized } \\
\text { protein }\end{array}$ & $\begin{array}{l}\text { Change in } \\
\lambda_{\max }(\mathrm{nm})\end{array}$ \\
\hline BSA $^{\mathrm{a}}$ & $341 \pm 1$ & $334 \pm 1$ & -7 \\
\hline $\mathrm{TLL}^{\mathrm{b}}$ & $340 \pm 1$ & $332 \pm 1$ & -8 \\
\hline Lysozyme $^{2}$ & $345 \pm 1$ & $338 \pm 1$ & -7 \\
\hline $\mathrm{CRL}^{\mathrm{c}}$ & $334 \pm 1$ & $330 \pm 1$ & -4 \\
\hline
\end{tabular}

aBSA = Bovine serum albumin, ${ }^{\mathrm{b}} \mathrm{TLL}=$ Thermomyces lanuginosus lipase, ${ }^{\mathrm{C}} \mathrm{CRL}=$ Candida rugosa lipase.

environment of the aromatic residues. It has been shown that lyophilized preparations of $\alpha$-chymotrypsin show poor esterification/transesterification activity in low water media containing organic solvents ${ }^{25}$. Low activities of lyophilized powders in such media have been explained due to structural changes which occur upon lyophilization ${ }^{14}$. "Dry" preparations obtained by precipitation of $\alpha$-chymotrypsin from its aqueous solution by addition of water miscible organic solvents are known to show 


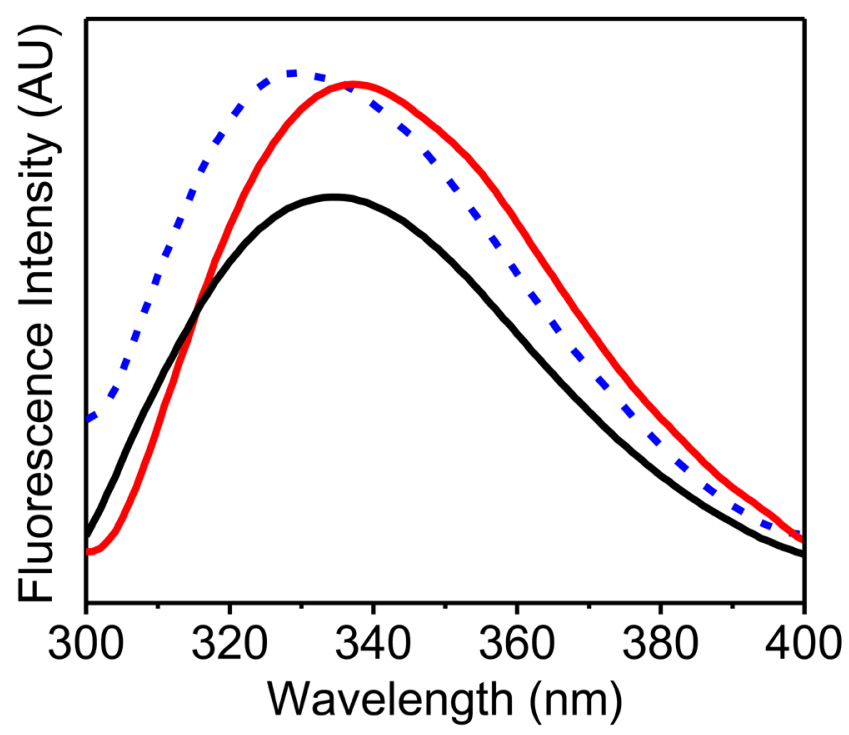

Figure 2 Fluorescence emission spectra (AU, arbitrary units) of $\alpha$-chymotrypsin. $\alpha$-Chymotrypsin in aqueous buffer $(10 \mathrm{mM}$ Tris-HCl, pH 7.0) (black curve), lyophilized $\alpha$-chymotrypsin powder (blue dashed curve) and solid sample of enzyme precipitated and rinsed with propanol (EPRP) of $\alpha$-chymotrypsin (red curve). All these fluorescence emission spectra were recorded with excitation at $280 \mathrm{~nm}$ using excitation and emission slit widths of $2 \mathrm{~nm}$ and $5 \mathrm{~nm}$, respectively.

Figure 2 Fluorescence emission spectra of $\alpha$-chymotrypsin.

1 Data File

http://dx.doi.org/10.6084/m9.figshare.640096

much better activities in low water media ${ }^{15,26,27}$. Recently, Solanki et al. ${ }^{15}$ found that changes in the CD spectra upon "drying" correlated well with catalytic activities in low water media for various $\alpha$-chymotrypsin preparations. A high activity preparation of $\alpha$-chymotrypsin for low water media (EPRP) ${ }^{15}$ showed a very small red shift in the emission $\lambda_{\text {max }}$ to $337 \mathrm{~nm}$ with an increase in the intensity of the emission spectra, in contrast to the lyophilized protein which showed a blue shift. This further highlights that the lyophilized protein is different from the high activity preparation (EPRP) in terms of the tertiary structure, demonstrating that the simple fluorescence method proposed here can successfully monitor changes in the tertiary structure of different types of formulations of solid proteins.

To further examine the application of this new method, we recorded the fluorescence spectra of the lyophilized formulation of recombinant GFP. In this case, the high intrinsic fluorescence of GFP due to the cyclic moiety present in the protein, which is very sensitive to changes in the structure of protein ${ }^{23}$, was studied (Figure 3). The lyophilized protein showed a considerable decrease in the intensity of the fluorescence emission

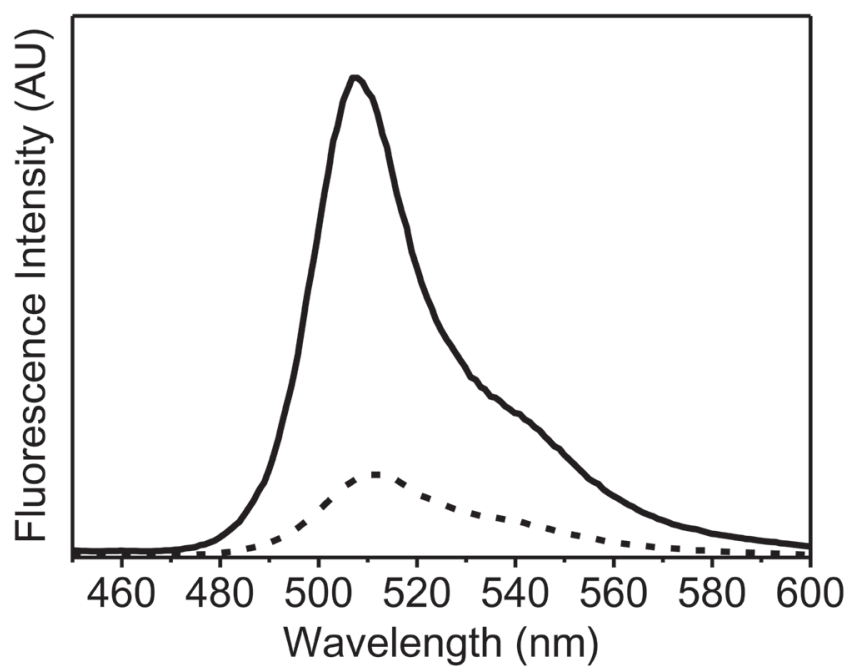

Figure 3 Fluorescence emission spectra (AU, arbitrary units) of green fluorescent protein (GFP). GFP in aqueous buffer (50 mM PBS) (solid line) and lyophilized powder of GFP (dashed line). These fluorescence emission spectra were recorded with excitation at $395 \mathrm{~nm}$ using excitation and emission slit widths of $2 \mathrm{~nm}$ and $5 \mathrm{~nm}$, respectively.

Figure 3 Fluorescence emission spectra of green fluorescent protein (GFP).

1 Data File

http://dx.doi.org/10.6084/m9.figshare.640097

spectra to $17 \%$ as compared to that of GFP in solution. The emission $\lambda_{\max }$ was also slightly red shifted upon lyophilization $(4 \mathrm{~nm}$, from $508 \mathrm{~nm}$ to $512 \mathrm{~nm}$ ). These changes (in fluorescence intensity and shift of $\lambda_{\text {max }}$ emission) were opposite to what was observed with other proteins (Figure 1). Visser et al. ${ }^{20}$ have shown that the fluorescence of the cyclic chromophore in GFP results from the energy transfer from the tryptophan. Figure 4 shows that the energy transfer between the tryptophan and the cyclic chromophore is much less in the lyophilized form. It is noteworthy that the change in the emission intensity due to tryptophan residues (at $-340 \mathrm{~nm}$ ) was observed in GFP (Figure 4), just as for the other proteins (Figure 1). Both changes reflect how the microenvironment affects the emission fluorescence of the unique chromophore of GFP and could be due to the degradation of this cyclic chromophore upon lyophilization.

\section{Conclusion}

A simple method of placing the dry protein powder in a 96-well microplate enables the generation of fluorescence spectra of a protein in the solid state. As the fluorescence spectra of the solution can also be recorded in an identical fashion, the exact comparison between the solution and solid state spectra is possible. 


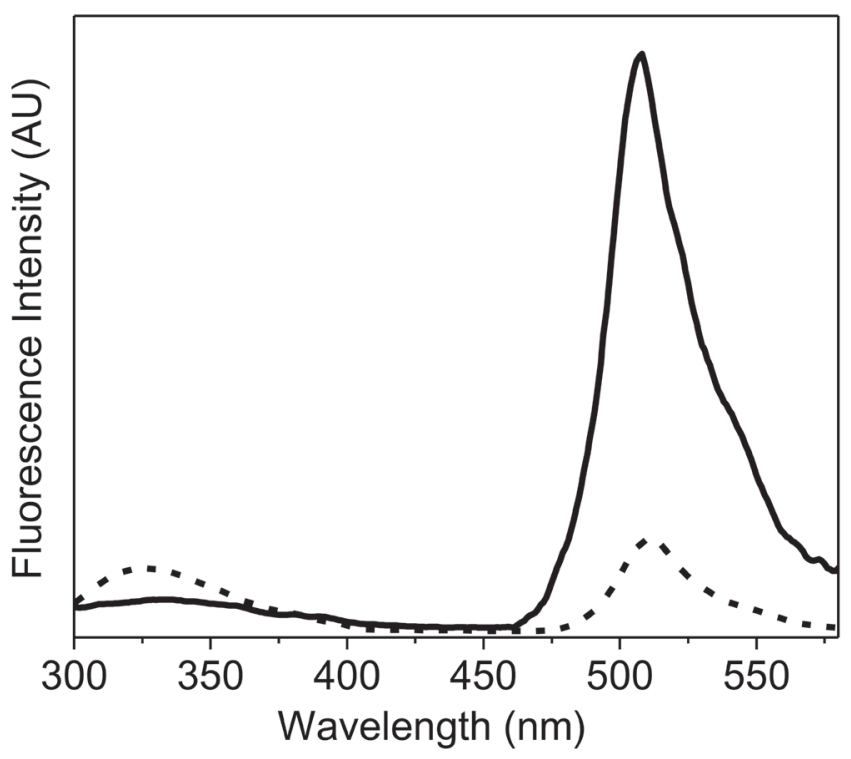

Figure 4 Fluorescence emission spectra (AU, arbitrary units) of green fluorescent protein (GFP) showing fluorescence resonance energy transfer (FRET) between tryptophan (Trp57) and cyclic chromophore. GFP in aqueous buffer (50 mM PBS) (solid line) and lyophilized powder of GFP (dashed line). These fluorescence emission spectra were recorded with excitation at $295 \mathrm{~nm}$ using excitation and emission slit widths of $2 \mathrm{~nm}$ and $5 \mathrm{~nm}$, respectively.

Figure 4 Fluorescence emission spectra of green fluorescent protein (GFP) showing fluorescence resonance energy transfer (FRET) between tryptophan (Trp57) and cyclic chromophore.

1 Data File

http://dx.doi.org/10.6084/m9.figshare.640098
Author contributions

MNG designed the study. MNG and SG participated in the interpretation of data and the writing of the manuscript. SG carried out the experimental work. Both authors approved the submission of the final manuscript.

\section{Competing interests}

No relevant competing interests where disclosed.

\section{Grant information}

This work was funded by research support from the Department of Biotechnology (DBT) [Grant number: BT/PR14103/ BRB/10/808/2010] and the Department of Science and Technology (DST) [Grant number: SERB/F/1776/2011-2012], Government of India. Financial support was also provided by the Council of Scientific and Industrial Research to SG in the form of a Junior Research Fellowship.

\section{Acknowledgments}

The financial support provided by the Council of Scientific and Industrial Research to SG in the form of a Junior Research Fellowship is gratefully acknowledged.
1. Royer CA: In: Shirley BA (ed) Protein stability and folding. Humana Press, Totowa, New Jersey (1995).

2. Lakowicz JR: Principles of fluorescence spectroscopy. 3rd edn., Springer, New York. (2009).

3. Brand L, Johnson ML: Methods in Enzymology. Academic Press, San Diego (2008); 150.

4. Agnew BJ, Murray D, Patton WF: A rapid solid-phase fluorescence-based protein assay for quantitation of protein electrophoresis samples containing detergents, chaotropes, dyes, and reducing agents. Electrophoresis. (2004); 25: 2478-2485.

5. Torres-Salas P, del Monte-Martinez A, Cutiño-Avila B, et al: Immobilized biocatalysts: novel approaches and tools for binding enzymes to supports. Adv Mater. (2011); 23: 5275-5282.

6. Lower BH, Yongsunthon R, Vellano FP 3rd, et al: Simultaneous force and fluorescence measurements of a protein that forms a bond between a living bacterium and a solid surface. J Bacteriol. (2005); 187: 2127-2137.

7. Ramachander R, Jiang Y, Li C, et al: Solid state fluorescence of lyophilized proteins. Anal Biochem. (2008); 376: 173-182.

8. Kostov Y, Albano CR, Rao G: All solid-state GFP sensor. Biotechnol Bioeng. (2000); 70: 473-477.

9. Leppänen A, Cummings RD: Fluorescence-based solid-phase assays to study glycan-binding protein interactions with glycoconjugates. Methods Enzymol. (2010); 478: 241-264.
10. Muller M, Milori DM, Déléris S, et al: Solid-phase fluorescence spectroscopy to characterize organic wastes. Waste Manag. (2011); 31: 1916-1923.

11. Mattiasson B, Adlercreutz P: Tailoring the microenvironment of enzymes in water-poor systems. Trends Biotechnol. (1991); 9 : 394-398.

12. Gupta MN: Enzyme function in organic solvents. Eur J Biochem. (1992); 203: 25-32.

13. Anthonsen T, Sjursens BJ: In: Gupta MN (ed) Methods in nonaqueous enzymology. Birkhauser Verlag, Basel (2000).

14. Lee M, Dordick J: Enzyme activation for nonaqueous media. Curr Opin Biotechnol. (2002); 13: 376-384.

15. Solanki K, Gupta MN, Halling PJ: Examining structure-activity correlations of some high activity enzyme preparations for low water media. Bioresour Technol. (2012); 115: 147-151.

16. Desie G, Boens N, De Schryver FC: Study of the time-resolved tryptophan fluorescence of crystalline alpha-chymotrypsin. Biochemistry. (1986); 25: 8301-8308.

17. Sharma VK, Kalonia DS: Steady-state tryptophan fluorescence spectroscopy study to probe tertiary structure of proteins in solid powders. J Pharm Sci. (2003); 92: 890-899.

18. Varian Cary Eclipse Fluorescence Spectrophotometer.[cited March 2013], Available from:http://www.chem.agilent.com/Library/ brochures/Cary-Eclipse_FLR-brochure.pdf. 16pp 
19. Horiba Jobin Yvon Florescence Technical Note FL-6: Fluorescence in Small or Solid Samples. [Cited March 2013] available at from:http://www.horiba.com/fileadmin/uploads/Scientific/ Documents/Fluorescence/Small_Samples_FL-6.pdf. 2pp

20. Visser NV, Borst JW, Hink MA, et al: Direct observation of resonance tryptophan-to-chromophore energy transfer in visible fluorescent proteins. Biophys Chem. (2005); 116: 207-212.

21. James NG, Ross JA, Stefl M, et al: Applications of Phasor Plots to in Vitro Protein Studies. Anal Biochem. (2011); 410: 70-76.

22. Dalal S, Raghava S, Gupta MN: Single-step purification of recombinant green fluorescent protein on expanded beds of immobilized metal affinity chromatography media. J Biochem Eng (2008); 42: 301-307.

23. Tsien RY: The green fluorescent protein. Annu Rev Biochem.
(1998); 67: 509-544.

24. Bradford MM: A rapid and sensitive method for the quantitation of microgram quantities of protein utilizing the principle of proteindye binding. Anal Biochem. (1976); 72: 248-254.

25. Triantafyllou AO, Wehtje E, Adlercreutz P, et al: Effects of sorbitol addition on the action of free and immobilized hydrolytic enzymes in organic media. Biotechnol Bioeng. (1995); 45: 406-414.

26. Roy I, Gupta MN: Preparation of highly active alpha-chymotrypsin for catalysis in organic media. Bioorg Med Chem Lett. (2004); 14: 2191-2193

27. Majumder AB, Singh B, Gupta MN: Diastereoselective synthesis of (R)-(alkyl)-beta-D-galactopyranoside by using beta-galactosidase (Aspergillus oryzae) in low-water media. Bioorg Med Chem Lett. (2008); 18: 124-128. 


\section{Open Peer Review}

\section{Current Peer Review Status: ? ?}

\section{Version 1}

Reviewer Report 15 March 2013

https://doi.org/10.5256/f1000research.872.r838

(C) 2013 Uversky V. This is an open access peer review report distributed under the terms of the Creative Commons Attribution License, which permits unrestricted use, distribution, and reproduction in any medium, provided the original work is properly cited.

\section{Vladimir Uversky \\ Department of Molecular Medicine, Department of Molecular Medicine, University of South Florida, Tampa, FL, USA}

The suggested technique for the analysis of solid state fluorescence of proteins is simple and can find multiple applications. Although the authors analyzed both fluorescence intensity and $\lambda_{\max }$ of protein powders and corresponding protein solutions, the applicability of fluorescence intensity is questionable. In fact, fluorescence intensity depends on a wide range of factors and cannot be easily interpreted, especially if samples are in different aggregated states (solid versus solution). Therefore, only $\lambda_{\max }$ should be taken as a parameter for analysis since this characteristic has understandable physical grounds.

Competing Interests: No competing interests were disclosed.

I confirm that I have read this submission and believe that I have an appropriate level of expertise to confirm that it is of an acceptable scientific standard, however I have significant reservations, as outlined above.

Author Response 15 Mar 2013

Munishwar N Gupta, Indian Institute of Technology Delhi, New Delhi, India

The references provided in the manuscript to the earlier work carried out with commercial accessories described differences between the solution spectra and the solid state spectra and list changes in both intensity and $\lambda_{\max }$ shift. In order to validate our method, we wanted to point out that both/similar changes occur with our method as well. However, as Table 1 of our manuscript shows, we have focused on the peak position. The amended manuscript can point out that intensities can be affected by many variables and one should rely more upon the $\lambda_{\max }$ position. These explanations can be added in the amended manuscript. 
Competing Interests: No competing interests were disclosed.

Reviewer Report 13 March 2013

https://doi.org/10.5256/f1000research.872.r834

(C) 2013 Rotello V. This is an open access peer review report distributed under the terms of the Creative Commons Attribution License, which permits unrestricted use, distribution, and reproduction in any medium, provided the original work is properly cited.

\section{Vincent Rotello}

Department of Chemistry, University of Massachusetts Amherst, Amherst, MA, USA

The use of solid state fluorescence to provide protein quality control is a modest technical advance. This study looks at both fluorescence peak position and intensity. The latter value, however, will be affected by light scattering that is both particle size and morphology dependent. I would suggest focusing on the peak position as this will provide a much better metric.

Competing Interests: No competing interests were disclosed.

I confirm that I have read this submission and believe that I have an appropriate level of expertise to confirm that it is of an acceptable scientific standard, however I have significant reservations, as outlined above.

Author Response 15 Mar 2013

Munishwar N Gupta, Indian Institute of Technology Delhi, New Delhi, India

1. The work is not aimed at suggesting that fluorescence emission spectroscopy should be applied to solid samples of proteins instead of using their solutions. On the other hand, as discussed in the manuscript, there are many investigations (enzyme immobilization on solid surfaces, enzyme powders in low water enzymology) wherein structural characterization would be valuable with the solid state samples. The availability of some commercial accessories fulfills this need. So, we offer a way of measuring fluorescence spectra in a 96well format without any additional accessories.

2. The 96-well plates used were black from all sides except from the top. So, the emission takes place along the same path direction as the exciting radiation. This minimizes scattered light and distortion of the spectra. This results in the spectra which are of reasonable quality as seen in our raw data.

3. The references provided in the manuscript to the earlier work carried out with commercial accessories described differences between the solution spectra and the solid 
state spectra and list changes in both intensity and $\lambda$ max shift. In order to validate our method, we wanted to point out that both/similar changes occur with our method as well. However, as Table 1 of our manuscript shows, we have focused on the peak position. In the amended manuscript we will point out that intensities can be affected by many variables and that one should rely more upon the $\lambda$ max position. These explanations will be added to our amended manuscript.

Competing Interests: No competing interests were disclosed.

The benefits of publishing with F1000Research:

- Your article is published within days, with no editorial bias

- You can publish traditional articles, null/negative results, case reports, data notes and more

- The peer review process is transparent and collaborative

- Your article is indexed in PubMed after passing peer review

- Dedicated customer support at every stage

For pre-submission enquiries, contact research@f1000.com 